\title{
Epidemiology and medical prediction of microbial keratitis in southeast Brazil
}

\author{
Epidemiologia e previsibilidade no diagnóstico clínico de ceratite microbiana no \\ sudeste do Brasil
}

Marlon Moraes Ibrahim ${ }^{1}$, Rafael Vanin ${ }^{2}$, Fuad Moraes Ibrahim ${ }^{1}$, Wellington de Paula Martins ${ }^{3}$, Rodrigo Teixeira de Campos Carvalho ${ }^{1}$, Rosane Silvestre de Castro², Eduardo Melani Rocha ${ }^{1}$

\section{ABSTRACT}

Purpose: The goals of the study were the following: 1) to show the epidemiology of microbial keratitis (MK) in the southeast Brazil, 2) to compare the epidemiological differences between fungal (FK) and bacterial keratitis (BK), and 3) to evaluate the frequency which ophthalmologists accurately differentiate bacterial keratitis from fungal keratitis based on clinical diagnosis.

Methods: A retrospective chart analysis of all clinically diagnosed microbial keratitis patients presenting between October, 2003 and September, 2006 was performed. Demographic features, ocular and laboratory findings, and information regarding the risk factors and clinical evolution were recorded.

Results: Among 118 consecutive patients with a clinical diagnosis of microbial keratitis, the positive culture rate was $61 \%$. The predominant bacterial and fungal pathogens isolated were S. epidermidis and Fusarium spp. Prior corneal injury was more frequent among fungal keratitis than bacterial keratitis cases $(p<0.0001)$. Coexisting systemic diseases, ocular diseases, and previous ocular surgery were more frequent among BK cases ( $p=0.001 ; p=0.001 ; p=0.004$; respectively). The following clinical findings were more frequent in bacterial keratitis: hypopion, corneal peripheral superficial vascularisation, and ulceration area $>20 \mathrm{~mm}^{2}(p<0.05)$. The diagnosis was predicted correctly in $81.6 \%$ of bacterial keratitis cases and in $48.1 \%$ of fungal keratitis cases.

Conclusion: Medical judgment of microbial keratitis agent is possible based on clinical and epidemiological data, but it is more difficult for fungal infection. Thus, such data cannot be the only basis for the diagnosis of suspected microbial keratitis, but oriented clinical suspicion based on these data may be beneficial for guiding antimicrobial treatment and earlier therapy.

Keywords: Eye infections, bacterial/epidemiology; Eye infections, bacterial/microbiology; Eye infections, bacterial/therapy; Eye infections, fungal/epidemiology; Eye infections, fungal microbiology; Eye infections, fungal/therapy; Risk factors

\section{RESUMO}

Objetivo: Os objetivos deste estudo foram os seguintes: 1) mostrar epidemiologia da ceratite microbiana (CM) no sudeste do Brasil, 2) para comparar as diferenças epidemiológicas entre ceratites fúngicas (CF) e bacterianas (CB) e 3) avaliar a frequência $\mathrm{com}$ que os oftalmologistas distinguem com precisão ceratite fúngica de ceratite bacteriana baseado no diagnóstico clínico.

Métodos: Uma análise retrospectiva de todas as ceratites microbianas diagnosticadas clinicamente apresentando entre outubro de 2003 e setembro de 2006 foi realizada. As características demográficas, relativas ocular e de laboratório, e informações aos fatores de risco e evolução clínica foram registrados.

Resultados: Dentre 118 pacientes consecutivos com diagnóstico clínico de ceratite microbiana, a taxa de cultura positiva foi de $61 \%$. Os patógenos predominantes de bactérias e fungos isolados foram S. epidermidis e Fusarium spp. O trauma de córnea foi mais frequente entre os casos de ceratite fúngica do que ceratite bacteriana ( $p<0,0001)$. A coexistência de doenças sistêmicas, doenças oculares e cirurgia ocular prévia foram mais frequentes entre os casos de ceratite bacteriana ( $p=0,001, p=0,001$, $p=0,004$, respectivamente). Os seguintes achados clínicos foram mais frequentes em ceratite bacteriana: hipópio, vascularização periférica da córnea superficial e área de ulceração $>20 \mathrm{~mm}^{2}(p<0,05)$. O diagnóstico foi corretamente estimado em $81,6 \%$ dos casos de CB e em 48,1\% dos casos de CF.

Conclusão: A presunção clínica do agente da ceratite microbiana é possível baseada em dados clínicos e epidemiológicos, mas é mais difícil para infecção fúngica. Assim, esses dados não podem ser a única base para o diagnóstico de suspeita de ceratite microbiana, mas a suspeita clínica orientada com base nesses dados pode ser benéfica para orientar o tratamento antimicrobiano e terapia precoce.

Descritores: Infecções oculares bacterianas/epidemiologia; Infecções oculares bacterianas/microbiologia; Infecções oculares bacterianas/terapia; Infecções oculares fúngicas/epidemiologia; Infecções oculares fúngicas/microbiologia; Infecções oculares fúngicas/terapia; Fatores de risco
Work carried out at the Department of Ophthalmology, São Paulo University - USP - Ribeirão Preto São Paulo, Brazil.

${ }^{1}$ Physicians, Department of Ophthalmology, Ribeirão Preto Medical School, São Paulo University USP - Ribeirão Preto (SP), Brazil.

2 Physicians, Department of Ophthalmology, Medical School, State University of Campinas UNICAMP - Campinas (SP), Brazil.

${ }^{3}$ Physician, Department of Gynecology and Obstetrics, Ribeirão Preto, School of Medicine, São Paulo University - USP - Ribeirão Preto (SP), Brazil.

Correspondence address: Eduardo M. Rocha. Department of Ophthalmology, Faculty of Medicine of Ribeirão Preto, University of São Paulo. Av. Bandeirantes, 3.900 - Ribeirão Preto (SP) CEP 14049-900 - E-mail: emrocha@fmrp.usp.br

Recebido para publicação em 08.06.2010

Última versão recebida em 25.11.2010

Aprovação em 26.11.2010

Nota Editorial: Depois de concluída a análise do artigo sob sigilo editorial e com a anuência do Dr. Sérgio Kwitko sobre a divulgação de seu nome como revisor, agradecemos sua participação neste processo.

\section{INTRODUCTION}

W ide geographical variation exists in the epidemiology of microbial keratitis (MK) based on economic and climate factors $^{(1)}$. Fungal keratitis (FK) accounts for about $50 \%$ of all cases of culture-proven MK in some developing countries ${ }^{(1-3)}$. The protracted course of the condition and the diversity of clinical presentation may contribute to unfavourable outcomes ${ }^{(4-5)}$.

Although diagnosis and treatment of FK and bacterial keratitis (BK) are based on isolation of the etiological agent, our hypothesis is that a detailed clinical examination may help the ophthalmologist to reach a rapid, presumptive and highly predictive diagnosis as well as to select empirical antimicrobial treatment to a favourable outcome. To improve the chances, epidemiological information is useful for a better initial medical decision on treatment.

The objectives of the present investigation were the following: 1) to present a descriptive statistics of consecutive cases of MK (i.e., FK and $B K)$ in the southeast of Brazil, 2) to compare epidemiological and ocular findings between them, and 3) to evaluate the fre- 
quency of correct prediction of FK and BK by ophthalmologists on patients, first visit to a referral center in this region.

\section{METHODS}

This retrospective study included all patients with clinically diagnosed MK treated at the Ophthalmology Clinic of the University Hospital, over a 3-year period from October, 2003 to September, 2006. Trained fellows supervised by a specialist evaluated the patients. The institution research ethics committee approved the study.

Records from 190 consecutive patients with diagnosis of keratitis were identified and reviewed by two investigators. The inclusion criterion was the presence of corneal ulceration, defined as a loss of the corneal epithelium with underlying stromal infiltration.

Obvious non-infectious or viral corneal diseases, including superficial injury of the cornea, corneal perforation, and corneal scars, including dendritic epithelial defect, recurrent epithelial defect without stromal infiltration, healing ulcers, autoimmune marginal keratitis, interstitial keratitis, and neurotrophic keratitis were excluded from the epidemiological analysis.

Demographic features, predisposing factors, history of trauma, associated ocular or systemic diseases were considered. Patients included in the study sought the hospital spontaneously or were referred by general practitioners or ophthalmologists. The presence and duration of symptoms and potential risk factors were compared with the clinical diagnosis.

Biomicroscopic findings were recorded and summarized by size, type, location, depth of ocular inflammation, and corneal ulceration. The reticule of the slit-lamp was used to measure the diameter of the inflammatory infiltrate, and the area was calculated from these dimensions. Inflammatory infiltrate was considered to be present when $>1 \mathrm{~mm}$ than the ulcer margin. The presence of corneal vessels was registered.

After instillation of anaesthetic eye drops ( $0.5 \%$ proxymetacaine hydrochloride, Anestalcon ${ }^{\circledR}$ - Alcon Labs, Brazil), corneal scrapings were collected aseptically, from the base and margin of the ulcers using a metal blade under direct vision through a slit-lamp. The samples were collected in the first visit, independently of antimicrobial topical drugs being used.

Smears were prepared for direct microscopy on Gram stained and $10 \% \mathrm{KOH}$ wet mounts. The material was also inoculated onto the surface of solid media (chocolate agar and Sabouraud's dextrose agar), as well as into liquid media (thioglycollate). Samples were incubated for 72 hours in the case of bacterial cultures and for four weeks, with daily observation, for fungal cultures. Results were considered negative when no growth was observed and positive when growth was present on at least two plates.

Correct prediction of FK or BK was defined as case conclusion with initial therapy. Whenever the microbiologic results were different from medical judgement, or changing antibiotic by antifungal or vice-versa after 48 hours of initial treatment at referral centre, it was considered incorrect prediction. Visual acuity (VA) improvement was defined as achievement of two or more lines of VA (Snellen Chart) compared to day 0.

To determine whether agricultural activities were related to keratitis, we defined the period between May and November as the harvest season and the period between December and April as the non-harvest season. This period correspond to the driest months in the southeast Brazil and the period of coffee and sugar cane harvest, main cultures in this region, in accordance with government official data from Instituto Nacional de Metereologia (INMET) (www.inmet.gov.br) and Empresa Brasileira de Pesquisa Agropecuária (EMBRAPA) (www.embrapa.br).

The diagnosis at the first visit were recorded and compared to the final analysis at the resolution of the case. It was used to evaluate the rate of correct prediction (i.e. FK or BK) comparing to clinical evolution and/or laboratory exams.
Fungal etiology was presumed when hyphal pattern, serrated margins, raised slough, dry textured slough, satellite lesions, and color (other than yellow) was observed in the corneal tissue during the slit lamp examination, as previously described ${ }^{(6)}$. In the opposite way, bacterial etiology was defined by clinical features (i.e.; flat, dry slough, margins well defined), hypopyon, keratic precipitates, flare or cells in the anterior chamber (AC), and deep lesions) added to case resolution with the adopted diagnosis. All included patients were followed for at least 30 days after the ulcers had healed and medication was discontinued.

Patients were treated with fortified antibiotics (gentamicin and cephalexin) or an antifungal agent (5\% natamycin) according to the first etiological impression of the corneal specialist until the results of cultures or smears became available. Next, the treatment for BK was guided by an antibiogram; patients who presented with FK or who had negative growth and did not respond to antibiotic treatment were treated with $5 \%$ natamycin. In this way, no patient was simultaneously treated with an antibiotic and an antifungal agent. When the medical judgment indicated fungal and it did not respond to natamycin, topical amphotericin was associated. A penetrant keratoplasty (PK) or conjunctival flaps were indicated when there was a risk of or confirmed perforation and evisceration with absence of cornea support and loss of intraocular content.

Descriptive statistics were applied, and clinical or epidemiological data were correlated with the laboratory diagnosis of bacterial and fungal agents using the Fisher exact test and the Chi-square test. Continuous variables were compared using Student's t-test or a nonparametric test (Mann-Whitney test). Statistical data were evaluated using Prism software, version 4 (Graph Pad, Inc., USA). Statistical significance was set at $p<0.05$

\section{RESULTS}

\section{MicRobiological PROFILE}

Among 190 patients with subsequent diagnosis of keratitis, 118 had a medical judgment of MK, which was found to be of BK in 66 (55.4\%) cases, FK in 52 (43.7\%) cases. Acanthamoeba keratittis $(n=1)$, herpetic keratitis $(n=31)$ as well as post-traumatic, neurotrophic, or autoimmune lesions $(n=40)$ were excluded. No bilateral cases were registered. The average follow-up period was 48.75 days $( \pm 12.90)$.

The total number of positive cultures was 73 of the $118 \mathrm{MK}$ cases (62.2\%).

Bacteria were recovered in culture from 56 corneal scrapings of 66 (85.0\%) patients with presumed BK and fungi were recovered from 17 scrapings of 52 (33.0\%) presumed FK. In 3 (2.5\%) of the 118 cases infective, bacteria and fungi were both isolated.

The predominant bacterial species isolated was Staphylococcus epidermidis (13 of 56; 23.21\%), followed by Staphylococcus aureus (10 of 56; 18\%). The predominant fungal species isolated was Fusarium spp. (11 of 17; 65\%), followed by Aspergillus (4 of 17; 24\%) (Table 1).

\section{Pre-referral conditions}

Fifty-four of 118 MK patients (45\%) were using topical antibiotics, including 24 (36\%) of the 66 with BK and 30 (58\%) of the 52 with FK. Thirty-nine of them (72\%) were on quinolones regimen.

Delays in obtaining any treatment occurred more often in cases of BK than FK, $14.4 \pm 25$ versus $6.6 \pm 7.1$ days ( $p=0.083$ ). Moreover, appropriate treatment tended to be more delayed for FK as compared to BK, $3.8 \pm 4.62$ versus $1.7 \pm 1.9$ days $(p=0.45)$, although not statistically significant in both comparisons.

Thirteen (11\%) patients were using antifungal agents, 10 (77\%) were taking amphotericin, 4 (31\%) were taking natamycin, 4 (31\%) 
Table 1. Bacterial and fungal pathogens isolated from eyes with microbial keratitis in a referral centre in southeast Brazil between 2003 and 2006

\begin{tabular}{lcc}
\hline & Total & $\mathbf{\%}$ \\
\hline Bacteria & $\mathbf{5 6}$ & $\mathbf{1 0 0 . 0 0}$ \\
\hline Total gram-positive cocci & 38 & 67.86 \\
S. epidermidis & 13 & \\
S. aureus & 10 & \\
S. pneumoniae & 8 & \\
Streptococcus sp & 3 & \\
Staphylococcus ssp & 2 & \\
Micrococcus & 1 & \\
S. dysgalactie & 1 & 3.57 \\
Total gram-positive bacilli & 4 & \\
Bacillus & 4 & 21.43 \\
Total gram-negative cocciand coccobacilli & 2 & \\
Neisseria gonorrhoeae & 2 & \\
Total gram-negative bacilli & 12 & \\
Serratia sp & 4 & \\
Pseudomonas aeruginosa & 4 & \\
Pantoea agglomerans & 23.53 \\
Morganella morgani & 11.77 \\
Klebsiella sp & 1 & \\
\hline Fungi & 1 & $\mathbf{1 0 0 . 0 0}$ \\
\hline Fusarium & 2 & \\
Aspergillus & 1 & \\
Penicillium & 2 & \\
\hline & & \\
\hline
\end{tabular}

were using both topical and systemic antifungals (ketoconazole), and $1(8 \%)$ was using both topical amphotericin and natamycin. These patients included 1 (2\%) of the 66 patients presumed to have BK, $10(19 \%)$ of the 52 patients presumed to have a fungal infection, and 2 (7\%) of the 31 presumed to have herpetic keratitis.

Referred patients with FK were more likely to be on antibiotics $(p=0.002$, Fisher's exact test) followed by antifungal agents $(p=0.003$, Fisher's exact test) (Table 2$)$.

Use of antibiotics before the medical prediction and smear collection for MK etiology occurred in 14 (37\%) of 38 bacterial culturepositive eyes and in 10 (36\%) of 28 bacterial culture-negative eyes. Previous use of antifungal drugs was present in 2 (12\%) of 17 fungal culture-positive eyes and in 8 (23\%) of 35 fungal culture-negative eyes. There was no statistically significant correlation between previous use of antibiotics and culture positivity $(p<0.05)$.

\section{DeMOgRAPHICS AND RISK COMPARISON BETWEen BACTERIAL AND FUNGAL KERATITIS}

A comparison of 118 patients diagnosed with MK revealed that frequency of males was higher among MK patients, but even higher among FK patients compared to BK ( $p=0.0035$; OR: 3.92; $95 \% \mathrm{Cl}$ : 1.53 - 10.03). In addition, these patients were younger (the mean age of BK patients was $50.59 \pm 20.99$ years and the mean age of FK patients was $41.18 \pm 17.49$ years, $p=0.016$, Student $t$-test) (Table 3 ). The proportion of patients from rural areas or who performed outdoor work was higher among FK cases compared to BK cases (Table 4).

The monthly/seasonal distribution of all 118 cases of MK analysed over a 3-year period revealed a higher incidence of cases between May and November, the harvest season, with a greater number of FK cases. This tendency was also observed for BK. No statistical significance was observed for the two conditions and therefore, no correlation could be calculated (Table 4).

A history of recent injury to the cornea predisposing it to MK was identified in 38 of 107 patients (36\%), whereas this information was not obtained in the other 12 cases. Injury was significantly more frequent for FK than BK and when the trauma involved a vegetative matter; injury was highly correlated with FK. On the other hand, features such as the presence of ocular or systemic disease as well as previous ocular surgery were more frequently correlated with BK (Table 4).

The clinical conditions associated with MK were the following for BK: diabetes mellitus in 7 patients, hypertension in 6, previous stroke in 4, autoimmune diseases in 2, immunosuppressive therapy in 2, Down syndrome in 1; and the following for FK: diabetes mellitus in 1, hypertension in 1, immunosuppressive therapy in 1 and skin diseases in 1 (Table 4).

\section{Clinical comparison between bacterial and FUNGAL KERATITIS}

The following assays were performed to evaluate whether ocular findings in MK would be more frequent in FK or BK

Hypopyon, superficial vessels, and stromal ulcerations $>20 \mathrm{~mm}^{2}$ were significantly more frequent in BK ( $p<0.05$, Fisher's exact test). However, stromal infiltrate was more frequent in FK ( $p<0.05$, Fisher's exact test). Other findings, such as chemosis and secretion were similar for both groups (Table 2).

Surgical intervention (e.g; PK, conjunctival flap or evisceration) was required in 28/118 (23.7\%) of MK, 15/66 (26.8\%) of BK and 13/52 (25\%) of FK. VA improvement was observed in 50/118 (42.8\%) of cases; $21 / 66$ (31.8\%) of BK, 29/52 (55.8\%) of FK, and 5/28 (17.9\%) of surgical cases of both groups.

All the three cases of simultaneous bacterial and fungal positive growth in culture smears had a medical judgment of FK and improved with antifungal treatment, without need of antibiotics, and were counted as FK in statistical analysis.

\section{Clinical prediction of bacterial and fungal keratitis}

In 79 (66\%) of 119 cases, the clinical diagnosis was predicted correctly at admission to the hospital. Of these, 53 (81.6\%) were bacterial infections, 25 (48.1\%) were fungal infections and 1 (100\%) was an acanthamoeba infection. Among herpetic cases, 25 (81\%) of 31 cases were predicted correctly. The probability of correct prediction was lower for FK than for BK ( $p=0.0004$, Fisher's exact test; OR: 4.40; 95\% Cl: 1.95 - 9.95).

\section{DISCUSSION}

A higher incidence of MK compared to total occurrence of keratitis was reported in Bangladesh $(82 \%)^{(7)}$, whereas similar incidences were reported in India ${ }^{(1)}(68.4 \%)$, and lower rate was reported in Taiwan $(40 \%)^{(8)}$.

The positive culture rate of $61 \%$ found here was similar to that reported in other studies (53-73\%) ${ }^{(9)}$. Lack of positivity is being attributed to various factors, although, prior treatment with topical antibiotics was not confirmed here (10-12). $^{\text {. }}$

The proportion of FK and BK or other causes of keratitis in the present study was similar to that observed in other studies conducted on the Indian subcontinent and Brazil(1,5,13-14). One possible explanation is that higher rates of successful community treatment of BK since the introduction of commercial topical quinolones in the late $1990 \mathrm{~s}^{(15)}$. Based on this hypothesis, only resistant cases and FK, whose treatment is less accessible, are sent to referral centres. In this regard, initiatives to find handle treatments for FK are worthwhile ${ }^{(16)}$.

FK etiological distribution here agrees with previous South American studies and may be attributed to climate and environment ${ }^{(13-14,17)}$. Fusarium spp have also been found to be the principal fungal pathogens in Florida, Nigeria, Tanzania, and Singapore. Aspergillus species predominate in Northern India, Nepal, and Bangladesh ${ }^{(18-19)}$. 
Table 2. Previous medications and principal signs and symptoms of patients with microbial keratitis between 2003 and 2006 in a referral center in southeast Brazil

\begin{tabular}{lccc}
\hline & $\begin{array}{c}\text { Bacterial keratitis } \\
\mathbf{n}(\%)\end{array}$ & $\begin{array}{c}\text { Fungal keratitis } \\
\mathbf{n}(\%)\end{array}$ & $\begin{array}{c}\text { Fisher's exact test } \\
\boldsymbol{p} \text { value }\end{array}$ \\
\hline $\begin{array}{l}\text { Previous medication } \\
\text { Antibiotics }\end{array}$ & $24(36.36)$ & $30(57.70)$ & $0.026^{*}$ \\
$\quad$ Antifungal & $2(3.03)$ & $10(19.23)$ & $0.005^{*}$ \\
Symptoms & & & \\
Red eye & $55(89.22)$ & $42(87.00)$ & 1.00 \\
Pain & $56(90.32)$ & $43(87.55)$ & 0.76 \\
Photophobia & $42(67.74)$ & $39(86.67)$ & $0.039^{*}$ \\
Poor vision & $43(71.67)$ & $43(93.49)$ & $0.0053^{*}$ \\
Signs & & & \\
Chemosis & $21(36.84)$ & $18(36.73)$ & 1.00 \\
Secretion & $17(30.36)$ & $11(22.92)$ & 0.51 \\
Hypopyon & $15(36.59)$ & $7(16.67)$ & $0.049^{*}$ \\
Superficial vessels & $17(34.00)$ & $6(13.64)$ & $0.030^{*}$ \\
Raised slough & $21(45.65)$ & $15(42.86)$ & 0.82 \\
Stromal infiltrate & $44(66.67)$ & $44(84.61)$ & $0.033^{*}$ \\
Stromal ulceration $>20$ mm ${ }^{2}$ & $35(53.85)$ & $12(26.09)$ & $0.0038^{*}$ \\
Stromal ulceration >one-third depth & $28(58.33)$ & $16(44.44)$ & 0.83 \\
\hline
\end{tabular}

Table 3. Demographic characteristics of 118 patients with microbial keratitis between 2003 and 2006 in a referral center in southeast Brazil

\begin{tabular}{|c|c|c|c|}
\hline Demographic characteristics & Total number of cases (\%) & Bacterial (\%) & Fungal (\%) \\
\hline Total number of cases & $118(100.00)$ & $66(55.93)$ & $52(44.07)$ \\
\hline \multicolumn{4}{|l|}{ Age (years) } \\
\hline$<21$ & $14(12.06)$ & $8(13.15)$ & $6(13.33)$ \\
\hline $21-30$ & $10(8.62)$ & $1(1.64)$ & $9(20.00)$ \\
\hline $31-40$ & $12(10.34)$ & 7 (14.48) & $5(11.11)$ \\
\hline $41-50$ & $33(28.45)$ & $11(18.03)$ & $12(26.67)$ \\
\hline$>51$ & $47(40.52)$ & $34(55.54)$ & $13(28.89)$ \\
\hline \multicolumn{4}{|l|}{ Gender } \\
\hline Male & $86(72.88)$ & $41(62.12)$ & $45(86.53)$ \\
\hline Female & $32(27.12)$ & $25(37.88)$ & 7 (13.47) \\
\hline \multicolumn{4}{|l|}{ Residence } \\
\hline Rural & $68(73.12)$ & $10(17.86)$ & $22(59.46)$ \\
\hline Urban & $25(26.88)$ & $46(82.14)$ & $15(40.54)$ \\
\hline \multicolumn{4}{|l|}{ Occupation } \\
\hline Indoorwork & $44(46.31)$ & $33(63.46)$ & $11(25.58)$ \\
\hline Retired & 20 & 17 & 3 \\
\hline Housewife & 13 & 9 & 4 \\
\hline Student & 7 & 4 & 3 \\
\hline Office worker & 3 & 2 & 1 \\
\hline Tailor & 1 & 1 & 0 \\
\hline Outdoorwork & $51(53.69)$ & $19(36.54)$ & $32(74.42)$ \\
\hline Agricultural & 33 & 9 & 24 \\
\hline Construction & 12 & 9 & 3 \\
\hline Cleaning & 6 & 1 & 5 \\
\hline
\end{tabular}

Staphylococcus epidermidis was the predominant bacterial species isolated in the present study. In India' and Nepal ${ }^{(18)}$, Streptococcus pneumoniae was the predominant bacterial pathogen. Pseudomonas spp. were the most common bacterial species in studies conducted in Bangladesh ${ }^{(7)}$, Hong Kong ${ }^{(20)}$ and Paraguay ${ }^{(17)}$. A predominance of Staphylococcus spp. has been reported in South Florida ${ }^{(21)}$. Again, differences that may be attributed to climate and environment.

FK and BK were reported here more frequently during the winter and spring, (harvest season between May and November), which was observed in previous studies ${ }^{(22)}$. This trend is likely to be a direct consequence of increased agricultural activity and/or higher proliferation of the mentioned pathogenic agents in the period.
The most common predisposing factor for MK in southeast Brazil is trauma, especially corneal injury due to vegetation; observation clearly connected with following risk factors.

Men in the middle decades of life are the main labor force for manual work, and are more involved in outdoor activities in Brazil, as also shown by other reports ${ }^{(23)}$. Farm work and other outdoor activities were usually the most common occupations recorded for patients with FK in the present study. It agrees with a higher incidence of FK among male patients younger than 50 years. In contrast, BK was more frequent among male patients older than 50 years. Similar results have been reported by Bharathi et al. ${ }^{(5)}$. A recent retrospective study focusing on aging urban population in Brazil revealed that 
Table 4. Correlation between environmental and patient features for fungal keratitis, as compared to bacterial keratitis in a referral centre in southeast Brazil, between 2003 and 2006

\begin{tabular}{|c|c|c|c|c|c|}
\hline & BK & FK & OR & $\mathrm{Cl} 95 \%$ & $p$ value \\
\hline \multicolumn{6}{|l|}{ Environmental features } \\
\hline Rural area & 10/56 (18\%) & $15 / 37(41 \%)$ & 3.14 & $1.21-8.09$ & 0.0180 \\
\hline Outdoorwork & $11 / 44(35 \%)$ & $32 / 51(63 \%)$ & 5.05 & $2.08-12.28$ & 0.0004 \\
\hline Harvest season & $48 / 66(73 \%)$ & $41 / 52(79 \%)$ & 1.40 & $0.59-3.30$ & 0.5200 \\
\hline \multicolumn{6}{|l|}{ Patient features } \\
\hline Coexistence of ocular disease & $25 / 60(42 \%)$ & $6 / 48(12 \%)$ & 0.20 & $0.07-0.54$ & 0.0011 \\
\hline Previous ocular surgery & $20 / 63(32 \%)$ & $4 / 50(8 \%)$ & 0.19 & $0.06-0.61$ & 0.0045 \\
\hline Systemic illness & $22 / 63(35 \%)$ & $4 / 49(8 \%)$ & 0.17 & $0.05-0.55$ & 0.0013 \\
\hline Corneal trauma & 10/60 (17\%) & $28 / 47(60 \%)$ & 7.37 & $3.01-18.03$ & $<0.0001$ \\
\hline Vegetal corneal injury & 2/10 (20\%) & $22 / 28(79 \%)$ & 14.67 & $2.44-88.17$ & 0.0019 \\
\hline
\end{tabular}

$\mathrm{BK}=$ bacterial keratitis; $\mathrm{FK}=$ fugal keratitis; $\mathrm{OR}=$ odds ratio; $\mathrm{Cl}=$ confidence interval

male gender as a risk factor is attenuated, and ocular surgery has become a major risk factor ${ }^{(24)}$. Those interdependent aspects must be considered in clinical prediction of the etiologic agent.

The ocular and systemic predisposing factors recorded here revealed less influence than those reported in other studies ${ }^{(25)}$, but were similar to a recent report, except for the higher frequency of Pseudomonas spp in Bangkok ${ }^{(26)}$.

The use of contact lenses, a major risk factor for MK in many studies ${ }^{(27-28)}$. was not a risk factor in the population studied here, since very few patients using the public health system wear contact lenses in Brazil.

One other major issue addressed is the adequacy of initial medical therapy for MK based on clinical findings. This is justified by the large number of negative results of laboratory smears and the critical relevance of initial therapy for MK progression ${ }^{(29)}$. It is well known that empirical treatment for BK is used in most mild to moderate cases. Therefore, the frequent update and report in regional agents prevalence and risk factors by reference centers are more important for medical judgment to distinguish BK from FK for earlier and appropriate treatment than published guidelines written by experts $(28,30)$

As observed before, fungal isolation from keratitis takes a longer time and negative results are higher than those obtained from BK, with rates that varies from 40 to $70 \%{ }^{(11,31)}$.

One potential bias in the present study was the assumption that a cure for MK without proper medication is rare. Therefore, cases successfully resolved, even though culture-negative, were included in the FK group or BK group. It is also possible that an eye with keratitis, unresponsive to the initial therapy tried, and then introduced to a different one, resolved because of the development of corneal neovascularization or other innate immune mechanisms.

Recent works intended to diagnosis MK based on clinical features were able to achieve predictive values for FK from 45 to 83\%. This range is probably due to methodological differences and/or regional dominance of more characteristic agents ${ }^{(6,32)}$. The major findings considered were aspect of ulcers (i.e.; serrated margins, endothelial ring, dry, raised, necrotic, or fluffy surface and long history of symptoms. In the present series, previous trauma, symptoms such as photophobia and poor vision at presentation as well as signs such as typical stromal infiltrate (defined as $>1 \mathrm{~mm}$ larger than the ulcer margin) were more frequent in FK. Moreover, patients with FK were more likely to have had previous treatment. On the other hand, signs that predicted BK were pre-existing ocular disease or surgery, hypopyon, peripheral superficial corneal vessels, and stromal ulceration $>20 \mathrm{~mm}^{2}$.

In conclusion, this study shows that it is likely that the climate, environment and patient inhabits determinates characteristics of MK. It also revealed that in southeast of Brazil MK is predominantly a professional disease. In addition, our study agrees that clinical featu- res of MK vary considerably and that no feature can be absolutely pathognomonic for an etiological agent. Although clinical examination cannot be the only basis for decision and corneal scraping for analysis is recommended, several times mandatory, ophthalmologists must be updated in MK epidemiology to manage a MK based on clinical findings.

\section{AKNOWLEDGMENT}

Financial Support: CNPq, Brazil.

\section{REFERENCES}

1. Srinivasan M, Gonzales CA, George C, Cevallos V, Mascarenhas JM, Asokan B, et al. Epidemiology and aetiological diagnosis of corneal ulceration in Madurai, south India. $\mathrm{Br}$ J Ophthalmol. 1997;81(11):965-71.

2. Hagan M, Wright $E_{1}$ Newman M, Dolin P, Johnson G. Causes of suppurative keratitis in Ghana. Br J Ophthalmol. 1995;79(11):1024-8.

3. Poole TR, Hunter DL, Maliwa EM, Ramsay AR. Aetiology of microbial keratitis in northern Tanzania. Br J Ophthalmol. 2002:86(8):941-2.

4. Rapoza PA, West SK, Katala SJ, Taylor HR. Prevalence and causes of vision loss in central Tanzania. Int Ophthalmol. 1991;15(2):123-9.

5. Bharathi MJ, Ramakrishnan R, Meenakshi R, Padmavathy S, Shivakumar C, Srinivasan M Microbial keratitis in South India: influence of risk factors, climate, and geographical variation. Ophthalmic Epidemiol. 2007;14(2):61-9.

6. Thomas PA, Leck AK, Myatt M. Characteristic clinical features as an aid to the diagnosis of suppurative keratitis caused by filamentous fungi. Br J Ophthalmol. 2005;89(12):1554-8.

7. Dunlop AA, Wright ED, Howlader SA, Nazrul I, Husain R, McClellan K, Billson FA. Suppurative corneal ulceration in Bangladesh. A study of 142 cases examining the microbiological diagnosis, clinical and epidemiological features of bacterial and fungal keratitis. Aust N Z J Ophthalmol. 1994:22(2):105-10.

8. Fong CF, Tseng CH, Hu FR, Wang IJ, Chen WL, Hou YC. Clinical characteristics of microbial keratitis in a university hospital in Taiwan. Am J Ophthalmol. 2004; 37(2):329-36.

9. Asbell P, Stenson S. Ulcerative keratitis. Survey of 30 years' laboratory experience. Arch Ophthalmol. 1982;100(1):77-80.

10. Badenoch PR, Coster DJ. Antimicrobial activity of topical anaesthetic preparations. Br J Ophthalmol. 1982;66(6):364-7.

11. Lalitha P, Prajna NV, Kabra A, Mahadevan K, Srinivasan M. Risk factors for treatment outcome in fungal keratitis. Ophthalmology. 2006;113(4):526-30. Comment in: Ophthalmology. 2007;114(3):617

12. Marangon FB, Miller D, Alfonso EC. Impact of prior therapy on the recovery and frequency of corneal pathogens. Cornea. 2004;23(2):158-64.

13. Höfling-Lima AL, Forseto A, Duprat JP, Andrade A, Souza LB, Godoy P, Freitas D. Estudo laboratorial das micoses oculares e fatores associados às ceratites. Arq Bras Oftalmol. 2005, 68(1):21-7.

14. Ibrahim MM, Vanini R, Ibrahim FM, Fioriti LS, Furlan EM, Provinzano LM, et al. Epidemiologic aspects and clinical outcome of fungal keratitis in southeastern Brazil. Eur J Ophthalmol. 2009;19(3):355-61

15. McLeod SD, Kolahdouz-Isfahani A, Rostamian K, Flowers CW, Lee PP, McDonnell PJ. The role of smears, cultures, and antibiotic sensitivity testing in the management of suspected infectious keratitis. Ophthalmology. 1996;103(1):23-8. Comment in: Ophthalmology. 1996; 103(8):1165-6

16. Oliveira LA, Takata TT, Shiguematsu Al, Melo Júnior LAS, Gompertz OF, Sousa LB, Mannis MJ. Effect of topical 0.5 percent povidone-iodine compared to 5 percent natamycin in fungal keratitis caused by Fusarium solani in a rabbit model: a pilot study. Arq Bras Oftalmol. 2008;71(6):860-4 
17. Miño de Kaspar H, Zoulek G, Paredes ME, Alborno R, Medina D, Centurion de Morinigo M, et al. Mycotic keratitis in Paraguay. Mycoses. 1991;34(5-6):251-4.

18. Upadhyay MP, Karmacharya PC, Koirala S, Tuladhar NR, Bryan LE, Smolin G, Whitcher JP. Epidemiologic characteristics, predisposing factors, and etiologic diagnosis of corneal ulceration in Nepal. Am J Ophthalmol. 1991;111(1):92-9.

19. Khanal B, Kaini KR, Deb M, Badhu B, Thakur SK. Microbial keratitis in eastern Nepal. Trop Doct. 2001;31(3):168-9.

20. Houang E, Lam D, Fan D, Seal D. Microbial keratitis in Hong Kong: relationship to climate, environment and contact-lens disinfection. Trans R Soc Trop Med Hyg. 2001; 95(4):361-7.

21. Liesegang TJ, Forster RK. Spectrum of microbial keratitis in South Florida. Am J Ophthalmol. 1980;90(1):38-47.

22. Leck AK, Thomas PA, Hagan M, Kaliamurthy J, Ackuaku E, John M, et al. Aetiology of suppurative corneal ulcers in Ghana and south India, and epidemiology of fungal keratitis. Br J Ophthalmol. 2002;86(11):1211-5.

23. Faria NMX, Facchini LA, Fassa AG, Tomasi E. Processo de produção rural e saúde na serra gaúcha: um estudo descritivo. Cad Saúde Pública = Rep Public Health. 2000; 16(1):115-28.

24. Passos RM, Cariello AJ, Yu MCZ, Höfling-Lima AL. Microbial keratitis in the elderly: a 32year review. Arq Bras Oftalmol. 2010;73(4):315-9.
25. Gopinathan U, Garg P, Fernandes M, Sharma S, Athmanathan S, Rao GN. The epidemiological features and laboratory results of fungal keratitis: a 10-year review at a referral eye care center in South India. Cornea. 2002;21(6):555-9.

26. Sirikul T, Prabriputaloong T, Smathivat A, Chuck RS, Vongthongsri A. Predisposing factors and etiologic diagnosis of ulcerative keratitis. Cornea. 2008;27(3):283-7.

27. Cohen EJ. Fusarium keratitis associated with soft contact lens wear. Arch Ophthalmol. 2006;124(8):1183-4. Comment on: Arch Ophthalmol. 2006;124(7):1051-3. Arch Ophthalmol. 2006:124(7):941-7.

28. Moriyama AS, Hofling-Lima AL. Contact lens-associated microbial keratitis. Arq Bras Oftalmol. 2008;71(6 Supl):32-6.

29. McLeod SD, LaBree LD, Tayyanipour R, Flowers CW, Lee PP, McDonnell PJ. The importance of initial management in the treatment of severe infectious corneal ulcers. Ophthalmology. 1995;102(12):1943-8.

30. Mc Donnell PJ. Empirical or culture-guided therapy for microbial keratitis? A plea for data Arch Ophthalmol. 1996;114(1):84-7.

31. Yilmaz S, Ozturk I, Maden A. Microbial keratitis in West Anatolia, Turkey: a retrospective review. Int Ophthalmol. 2007;27(4):261-8.

32. Dahlgren MA, Lingappan A, Wilhelmus KR. The clinical diagnosis of microbial keratitis. Am J Ophthalmol. 2007:143(6):940-4. 